\title{
Molecular mechanisms involved in the nutritional and hormonal regulation of growth in pigs
}

\author{
BY JOHN M. BRAMELD \\ Department of Applied Biochemistry and Food Science, University of Nottingham, \\ Sutton Bonington Campus, Loughborough LE12 5RD
}

Nutritional and hormonal factors are major determinants of animal growth and, postnatally at least, pituitary-derived growth hormone $(\mathrm{GH})$, via its stimulatory effects on insulin-like growth factor-I (IGF-I) production, is one of the major regulators of growth. The production of GH by the pituitary is under the local control of growth-hormone-releasing factor (GRF) and growth-hormone-release-inhibiting factor (somatostatin). However, diet also has a major effect on circulating $\mathrm{GH}$ concentrations, such that nutritional restriction leading to growth arrest is associated with a decrease in plasma IGF-I concentration, but an increase in plasma GH concentration in most species, including the pig (Buonomo \& Baile, 1991), the rat being the exception.

The molecular mechanisms for this growth arrest, in the presence of high concentrations of this positive regulator of growth $(\mathrm{GH})$, are proposed to be via dietary effects on the components of the GH-IGF axis, and in particular IGF-I, and form the subject for the present review.

\section{COMPONENTS OF THE GROWTH HORMONE-INSULIN-LIKE GROWTH FACTOR AXIS}

\section{Growth hormone receptor}

This resistance to $\mathrm{GH}$ action in situations of poor nutrition suggests nutritionally-sensitive control at the level of tissue responsiveness. The first step in the action of GH is in binding to the GH receptor (GHR), and ligand-binding studies have identified two classes of receptor with low and high binding affinities (Breier \& Sauerwein, 1995). The low-affinity receptor has been proposed to be due to GH binding to only one GHR molecule at low receptor concentrations, whereas the high-affinity receptor has been proposed to be due to GH binding to two distinct GHR molecules at high receptor concentrations (see Breier \& Sauerwein, 1995). The actual activation of the receptor and subsequent signal transduction requires the binding to two GHR molecules, resulting in receptor dimerization (for review, see Kelly et al. 1994), and this binding then promotes association of an intracellular tyrosine kinase (JAK2), and results in phosphorylation of both the GHR and JAK2 molecules. The subsequent steps in the second messenger pathway are as yet unclear. It would seem likely, therefore, that the first site for nutritional control may be in controlling the expression and/or production or second messenger signalling pathway of the GHR.

The GHR gene has been cloned in many species including pig (Cioffi et al. 1990), with the gene found to encode for a protein of about 638 amino acids with a relative molecular mass of about 70000 , and, due to sequence similarities, is a member of the cytokinehaematopoietic receptor superfamily (Kelly et al. 1991). The GHR molecule contains both intra- and extracellular domains, relating to $\mathrm{GH}$ binding (extracellular) and JAK2 association (intracellular). A plasma GH-binding protein (GHBP) has recently been identified in most species, including pig (Davis et al. 1992), and has been shown to have an identical amino acid sequence to that of the extracellular domain of the GHR. In rats and 
mice, the mechanism for production of this GHBP appears to be via an alternate transcript, as there are two RNA transcripts for GHR found in rat liver (Baumbach et al. 1989). However, in pigs and other species there is only one RNA transcript for GHR in liver (Louveau \& Etherton, 1992), and it has been shown in cultured cells that the extracellular domain of the GHR can be released by proteolytic cleavage of the membrane-bound receptor (Trivedi \& Daughaday, 1988). Thus, there are two possible mechanisms for nutritional-hormonal effects on growth, first via the GHR, which will affect GH action, and second via the GHBP, which may alter the half-life of GH, or affect its availability for binding to the GHR.

\section{Insulin-like growth factors}

The IGF (IGF-I and -II) are two polypeptide growth factors which are structurally related to proinsulin. They are made up of seventy (IGF-I) and sixty-seven (IGF-II) amino acids, with a molecular mass of 7.65 and $7.47 \mathrm{kDa}$ respectively, and share about $60 \%$ homology (for review, see Sussenbach et al. 1992). They have been shown to stimulate cell proliferation and differentiation, and to inhibit cell death (for review, see Jones \& Clemmons, 1995). The IGF have also been shown to stimulate protein synthesis, amino

(A)

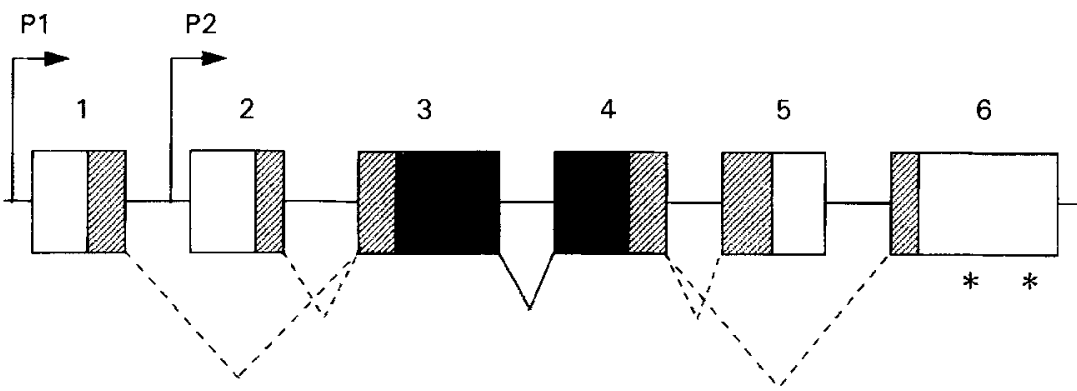

(B)

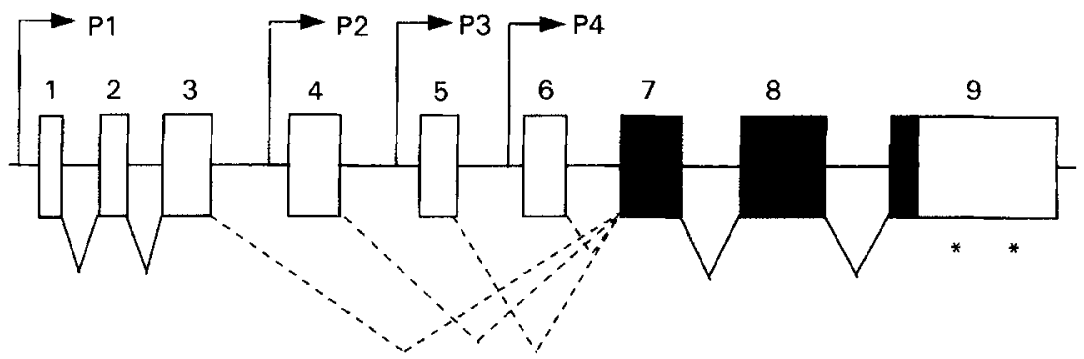

Fig. 1. Structures of the mammalian (A) insulin-like growth factor (IGF)-I and (B) IGF-II genes ( $\square, \square, \square$ ) showing the exons (1-6 for IGF-I and 1-9 for IGF-II); (-, ---), the introns (not to scale). (D), Coding sequence for the mature peptide; ( $\mathbb{C}$ ), coding sequence for the unprocessed peptide (prohormone); $(\square)$, untranslated sequence. $(\rightarrow$; P1-P2 (IGF-I), P1-P4 (IGF-II)), Alternative promoter initiation sites. *, Alternative polyadenylation sites. Primary mRNA molecules are derived from the splice permutations between alternatively-used exons $(---)$, and from the invariant splices (-) between exons 3 and 4 for IGF-I, and between exons 1, 2 and 3, and 7, 8 and 9 for IGF-II. (Adapted from Gilmour, 1994 and Sussenbach et al. 1992.) 
acid and glucose uptake, and to inhibit protein degradation in skeletal muscle cells in culture (Harper et al. 1987; Roe et al. 1989, 1995).

IGF-I has been shown to mediate many of the growth-promoting effects of GH, and is produced postnatally, mainly by the liver, under GH control and secreted into the circulation. However, it is now well established that most tissues are capable of producing IGF-I, which may then act in an autocrine or paracrine manner to promote tissue growth. Very few fetal tissues express IGF-I, presumably due to the very low levels of GHR expression, and, therefore, IGF-I is considered to be mainly a postnatal growth factor. The gene for IGF-I has been cloned in many species including pig (Weller et al. 1993), and has been shown to span nearly $90 \mathrm{~kb}$ DNA, and to consist of six exons (Fig. 1(A)). The first two exons ( 1 and 2 ) represent alternative pro-peptide domains and $5^{\prime}$-untranslated regions, which have associated transcriptional promoters, and result in two classes of transcript (the exon 1 promoter gives rise to class 1 transcripts). Exons 3 and 4 encode for the mature IGF-I polypeptide, and are present, therefore, in all transcripts, whereas exons 5 and 6 give rise to alternative E-domains and $3^{\prime}$-untranslated regions, likely to be involved in the processing and progress through the cell (see Sussenbach et al. 1992; Gilmour, 1994).

IGF-II is produced mainly in the fetus by a variety of tissues, and this high level of expression in the fetus has led to the suggestion that it is a fetal growth factor. The gene for IGF-II has been cloned in few species, with the only large farm animal apparently being the sheep ( $\mathrm{Li}$ et al. 1993). The gene contains nine exons (Fig. 1(B)), but this time the first six exons represent alternative $5^{\prime}$-untranslated regions and have four associated promoters. The first promoter (exons 1-3) is only active in the postnatal liver, whereas the other three promoters (exons 4, 5 and 6) are only active in the fetus. Exons 7, 8 and 9 encode for the IGF-II precursor, and exon 9 also gives rise to two alternative 3'-untranslated regions (see Sussenbach et al. 1992).

\section{Insulin-like growth factor-binding proteins}

The IGF, like GH, circulate in the blood and extracellular fluid bound to specific binding proteins, and, to date, there are known to be six distinct IGFBP (IGFBP-1-IGFBP-6). Five of these have been described in pigs (McCusker et al. 1985; Coleman et al. 1991). They differ in the factors which regulate them, and also in their relative affinities for the two IGF, with IGFBP-1, -3 and -4 having similar affinities for IGF-I and IGF-II, but IGFBP-2, -5 and -6 having a higher affinity for IGF-II. The predominant IGFBP in blood is IGFBP-3, which is associated with both the IGF and an acid-labile subunit (ALS) to form a $150 \mathrm{kDa}$ complex; other IGFBP found in pig blood include IGFBP-1, -2 and -4 (Coleman et al. 1991; Dauncey et al. 1993). Unlike many hormones, the IGF are not stored intracellularly, but are in fact synthesized and then released from the cell. It has been suggested, therefore, that the large $150 \mathrm{kDa}$ complex of IGF, ALS and IGFBP-3 may be a mechanism for storing the IGF and then transporting it to the site of action. The actual effects of the IGFBP on IGF activity remains unclear, with various IGFBP found to inhibit, enhance or have no effect on IGF activity in cultured cells, depending on conditions and relative times of addition of the IGFBP and IGF (for review, see Zapf, 1995). The genes for all six IGFBP have been cloned, and the gene structures are at varying stages of understanding, with sequences available to make molecular probes for virtually all IGFBP (for reviews, see Rechler \& Brown 1992; Jones \& Clemmons, 1995). However, no work has been published on the IGFBP genes in pigs. 


\section{Insulin-like growth factor receptors}

The actions of the IGF are mediated via two independent receptors (for review, see Jones \& Clemmons, 1995). The type-1 IGF-receptor (IGF-1R) is structurally similar to the insulin receptor and indeed binds insulin with a low affinity. The comparative binding of the three ligands to IGF-1R is IGF-I $>$ IGF-II $\gg$ insulin and, therefore, supraphysiological concentrations of insulin are able to exert IGF actions via the IGF-1R. The second receptor, the IGF-2R, has been shown to be the cation-independent mannose-6-phosphate receptor, and binds IGF-II with a greater affinity than IGF-I, and does not bind insulin at all. The elucidation of the second messenger pathways linking ligand binding to the various intracellular actions is still in its infancy. However, the IGF-1R is known to involve a tyrosine kinase activity and receptor phosphorylation, whereas the IGF-2R is reported to couple to a GTP-binding protein. There is a lack of published work on the regulation of IGF-receptor levels (protein or mRNA) in the pig, despite their obvious importance in the control of growth and metabolism. The studies carried out to date on the IGF-1R are in rats (Dardevet et al. 1991) or sheep (Glassford et al. 1995; Oldham et al. 1996), and all seem to indicate the major regulator of IGF-1R to be IGF-I itself. Any condition that results in decreased IGF-I concentrations (e.g. fasting, feed restriction or diabetes) results in increased IGF-1R expression (for review, see Werner et al. 1995).

\section{WHOLE-ANIMAL PIG STUDIES}

A number of groups have studied the effects of dietary manipulation and/or $\mathrm{GH}$ administration on pig growth, but few have tried to identify the mechanisms involved. The present review will look at the effects of diet and/or GH on the various components of the GH-IGF system, at both the gene and protein levels, and in particular at IGF-I, which is thought to be the main growth factor responsible for the changes in growth rate.

\section{Effects of manipulating energy availability}

Recent studies have demonstrated effects on growth and expression of GHR and IGF-I genes with increasing energy availability via intake and environmental temperature in young growing pigs (Dauncey et al. 1994; Weller et al. 1994). GHR expression in the liver was found to increase with food intake, whereas expression in longissimus dorsi (LD) muscle decreased with increased food intake and temperature (Dauncey et al. 1994). Strong positive correlations were observed between liver GHR mRNA and both plasma IGF-I concentration and growth rate, whereas a negative correlation was noted between LD muscle GHR mRNA and growth rate. Thus, the effects of intake and temperature on growth rate appeared to be mediated via control of liver GHR expression. However, it should be noted that plasma triiodothyronine $\left(\mathrm{T}_{3}\right)$ concentrations were affected by these manipulations, and that liver GHR mRNA and plasma $\mathrm{T}_{3}$ concentrations were also positively correlated. Thus, whether the dietary effects observed are direct nutrient effects on gene expression, or indirect via $\mathrm{T}_{3}$ remains to be answered.

A similar study was also carried out to study the effects of energy availability on IGF-I expression (Weller et al. 1994). The results were similar to the effects on GHR expression, in that expression in the liver increased with both intake and temperature, whereas expression in LD muscle decreased with increased intake and temperature. It was also found that major levels of class 2 transcripts (exon 2-containing transcripts) of IGF-1 were only present in the liver, a result also found in other whole-animal pig studies looking at 
differences with age (Brameld et al. 1995a) and breed of pig (Brameld et al. 1996a). Increased growth rates were accompanied by an increase in the proportion of class 2 IGF-I mRNA in the liver, suggesting a role for class 2 IGF-I in the endocrine growth response. It had previously been demonstrated that these dietary and temperature manipulations had no marked effects on circulating GH concentrations (Dauncey \& Buttle, 1990), but that there were significant effects on plasma concentrations of IGF-I (Dauncey et al. 1990), IGFBP-3 and IGFBP-2 (Dauncey et al. 1993), with both IGF-I and IGFBP-3 increasing with intake and temperature, whereas IGFBP-2 tended to decrease.

These results could all be explained by the hypothesis that dietary energy increases liver GHR expression, thereby increasing the ability of the liver to respond to the circulating GH. However, this hypothesis cannot be tested employing in vivo studies and, therefore, requires further study using in vitro cell culture methods.

\section{Effects of exogenous growth hormone}

A number of studies have been carried out to investigate the effects of $\mathrm{GH}$ administration on various components of the GH-IGF axis in pigs. Chronic administration of GH to pigs has been shown to increase GH binding to liver membranes (Chung \& Etherton, 1986; Ambler et al. 1992), but not to adipose tissue membranes (Sorensen et al. 1992), and to increase GHBP levels in pig serum, with the two being positively correlated (Ambler et al. 1992), suggesting that serum GHBP levels may reflect hepatic GHR numbers. We (Brameld et al. 1996b) have subsequently demonstrated GH-dependent increases in expression of both intra- and extracellular domains of the GHR in liver and skeletal muscle (both LD and semitendinosus), but not in adipose tissue (subcutaneous, omental or perirenal).

Exogenous GH has been shown to significantly increase plasma IGF-I concentrations in well-fed animals (Evock et al. 1990; Owens et al. 1990), and to either decrease (Owens et al. 1990) or have no effect on plasma IGF-II (Evock et al. 1990). Administration of GH to pregnant sows has also been shown to result in increased plasma IGF-I concentrations in their neonatal offspring $(20 \mathrm{~kg}$ ), but this effect is lost by the time the offspring reach market weight (Kelley et al. 1995). At the gene level, administration of GH has been shown to result in dose-dependent increases in IGF-I expression in both liver and subcutaneous adipose tissue, but not in LD muscle (Coleman et al. 1994). Studies at Nottingham (Brameld et al. 1996b) have similarly demonstrated GH-dependent increases in class 1 transcripts of IGF-I in liver, all three adipose tissue depots, and also in semitendinosus muscle, but not in LD muscle. Class 2 transcripts of IGF-I were only found in the livers of GH-treated pigs. Time-dependent increases in IGF-I mRNA have been shown as a result of a single GH injection in liver and subcutaneous and perirenal adipose tissues, with a slight increase also being seen in vastus lateralis muscle, but no effect in LD or semitendinosus muscles (Ramsay et al. 1995). Thus, different muscles appear to respond differently. GH has also been shown to decrease IGF-II expression in subcutaneous adipose tissue, and this effect was lessened by feeding an extra $100 \mathrm{~g}$ fat $/ \mathrm{kg}$ diet (Wolverton et al. 1992). The addition of dietary fat was shown to have no effect on the GH-stimulation of IGF-I expression in the same tissue.

As well as increasing circulating IGF-I concentrations, GH administration has been shown to increase IGFBP-3 and to decrease IGFBP-2 concentrations in serum (Coleman \& Etherton, 1991). The GH effects on IGFBP-2, however, appear to be dependent on dietary protein levels (Guan et al. 1997; see p. 612), with IGFBP-1 and -4 also being increased by GH (Guan et al. 1997). 
Thus, GH affects many of the components of the GH-IGF axis, not just IGF-I expression and production.

\section{Effects of manipulating dietary protein intake and growth hormone status}

Studies of the interaction between dietary protein intake and exogenous GH administration on plasma IGF-I concentrations in pigs have shown contrasting results, with increased protein shown to increase the response of plasma IGF-I to GH (Campbell et al. 1990; Caperna et al. 1990), or to have no effect on the GH response (Seve et al. 1993; Brameld et al. 1996b). However, the differences in dietary protein content in these studies were not restrictive (ranging from 83 to $270 \mathrm{~g} / \mathrm{kg}$ diet), unlike many of the studies carried out in rats, where crude protein $(\mathrm{N} \times 6.25)$ levels as low as $55 \mathrm{~g} / \mathrm{kg}$ have been used (Dardevet $e t$ al. 1991). The lack of effect of increasing dietary protein on GH-dependent increases in plasma IGF-I concentration was accompanied by a lack of effect on IGF-I expression (both class 1 and 2 transcripts) in pig liver (Grant et al. 1991; Brameld et al. 1996b). Increasing dietary protein intake (from 99 to $194 \mathrm{~g} / \mathrm{kg}$, however, was found to significantly increase class 1 transcripts of IGF-I in all three adipose tissue depots, and also to a smaller degree in semitendinosus muscle (Brameld et al. 1996b), but not in LD muscle (Grant et al. 1991; Brameld et al. 1996b). A significant positive interaction between dietary protein content and GH administration was observed on IGF-I expression in the adipose tissue depots (Brameld et al. 1996b).

Similar interactions were also observed on expression of GHR in liver, skeletal muscle and adipose tissue (Brameld et al. 1996b). However, the direction of the interaction was tissue specific, resulting in the highest level of GHR mRNA being in the high-protein-GHtreated group for liver, but in the low-protein-GH-treated group for muscle (LD and semitendinosus) and adipose tissue (subcutaneous, omental and perirenal).

Recent work at Nottingham has looked at the effects of dietary protein content and GH administration on the circulating IGFBP (Guan et al. 1997). IGFBP-3 and -1 were both increased at high dietary protein intake, but the dietary protein intake did not interact with the stimulatory effects of exogenous GH. The effect of exogenous GH on IGFBP-2 appears to be inhibited by increasing dietary protein intake, such that GH increased IGFBP-2 levels in the pigs fed on the lower-protein diets, but decreased IGFBP-2 levels in the pigs fed on the highest-protein diet $(194 \mathrm{~g} / \mathrm{kg})$. However, these effects were not statistically significant. Coleman \& Etherton (1991) reported that GH administration decreased plasma IGFBP-2 levels, but they do not state what diet the pigs were fed. It might be expected that a highnutrient (both energy and protein) diet would be given in order to meet the extra demands for growth.

Thus, dietary protein seems to affect both GHR and IGF-I expression, often in tissuespecific ways, as well as altering the circulating IGFBP levels, but further study is required using in vitro cell culture methods to identify whether these are direct nutrient effects on gene expression or indirect via manipulation of hormonal status.

\section{HEPATOCYTE CELL CULTURE STUDIES}

It can be seen that the whole-animal studies demonstrate effects of both dietary energy and protein on various components of the GH-IGF system in pigs, with some effects being seen at the mRNA level. However, the true mechanism for these nutrient and hormone effects cannot be determined in vivo, since the dietary manipulations also affect various circulating hormone levels, including GH, insulin, thyroid hormones and glucocorticoids. Thus, it is 
impossible to identify whether there are direct nutrient-gene interactions, or whether the observed effects are indirect via these circulating hormones.

The liver is the major site of IGF-I expression and production and, more specifically, the parenchymal cells (hepatocytes) are the main cellular site for expression of both GHR and IGF-I (van Neste et al. 1988; Uchijima et al. 1995). The liver is also a sensor of nutritional and metabolic status and, therefore, a primary site for nutrient-gene interactions. For these reasons we have established a primary pig hepatocyte culture system (Brameld et al. 1995b), in order to investigate the direct effects of various hormones and nutrients on the expression of GHR and IGF-I genes. For these studies it was essential to use a serum-free culture medium, and to identify which factors were necessary for maintenance of cell viability, in order to reduce the components of the basal medium to a minimum. Very little work in this area has been carried out using pig hepatocytes, with the majority of investigators using rat or chicken hepatocytes. It will be necessary, therefore, to widen the scope for the present discussion to include those species.

\section{Hormonal effects on hepatocyte expression and production}

We have demonstrated stimulatory effects of dexamethasone (Dex; a synthetic glucocorticoid) and both thyroid hormones $\left(\mathrm{T}_{3}\right.$ and thyroxine $\left(\mathrm{T}_{4}\right)$ ) on GHR expression, and also of Dex on IGF-I expression by pig hepatocytes, with $\mathrm{T}_{4}$ appearing to decrease IGF-I expression (Brameld et al. 1995b). When each of these hormones was added in combination with $\mathrm{GH}$, there was significant enhancement of the increases in class 1 transcripts obtained with GH alone, and the appearance of class 2 transcripts of IGF-I, presumably due to an increased number of GHR. Similar increases in class 1 transcripts, and the appearance of class 2 transcripts, were observed in the livers of GH-treated pigs (see p. 611). Studies in rat hepatocytes have produced similar effects of Dex on GH binding (Niimi et al. 1991), but conflicting effects of Dex on IGF-I, with Dex shown to either increase IGF-I expression and production (Phillips et al. 1991; Arany et al. 1993), or to have no effect on IGF-I expression and production (Miura et al. 1992; Uchijima et al. 1995). However, $T_{3}$ alone has been shown to have no effect on IGF-I expression or secretion (Uchijima et al. 1995), a similar result to that observed in the pig hepatocytes.

Studies using rat (Boni-Schnetzler et al. 1991; Phillips et al. 1991; Denver \& Nicoll, 1994) or chicken hepatocytes (Houston \& O'Neill, 1991) have demonstrated stimulatory effects of insulin on IGF-I expression (Boni-Schnetzler et al. 1991; Phillips et al. 1991) or production (Houston \& O'Neill, 1991; Denver \& Nicoll, 1994), with the effects of insulin and GH being additive when in combination (Boni-Schnetzler et al. 1991; Houston \& O'Neill, 1991). However, the pig hepatocytes died during prolonged culture without insulin, therefore insulin was always present in the cultures, and indeed appears to be the only essential hormone. The effect of insulin on pig hepatocyte IGF-I and/or GHR expression is, therefore, still unclear, especially as insulin has been shown to be essential for maintenance of protein synthesis and to increase both total and poly $(A)^{+}$RNA levels in rat hepatocytes (Hsu et al. 1992).

Glucagon has been shown to either inhibit IGF-I production, including GH-stimulated production and/or expression (Arany et al. 1993; Denver \& Nicoll, 1994), or to stimulate IGF-I expression and production, with an additive effect when in combination with GH (Kachra et al. 1991).

Last, epidermal growth factor (EGF) has been shown to increase IGF-I production in a dose-dependent manner (Barreca et al. 1992), which may be important in the process of liver regeneration after extensive organ mass loss. 
Hepatocytes have been shown to secrete mainly IGFBP-1 and -4 , but not IGFBP-3, which is only expressed in the non-parenchymal cells (Uchijima et al. 1995), with the various hormones described previously controlling their secretion into the culture medium. Culture medium concentrations of IGFBP-1 have been shown to be increased by Dex (Miura et al. 1992; Arany et al. 1993; Uchijima et al. 1995), glucagon (Kachra et al. 1991; Denver \& Nicoll, 1994; Uchijima et al. 1995) and EGF (Barreca et al. 1992), and to be decreased by insulin (Miura et al. 1992; Arany et al. 1993; Denver \& Nicoll, 1994; Uchijima et al. 1995), with $\mathrm{T}_{3}$ shown to have no effect (Uchijima et al. 1995) and $\mathrm{GH}$ to either have no effect (Uchijima et al. 1995), or to decrease secretion (Kachra et al. 1991; Miura et al. 1992; Thissen et al. 1994). IGFBP-4 secretion was found to be increased by Dex (Arany et al. 1993), $\mathrm{T}_{3}$ (Uchijima et al. 1995), insulin (Uchijima et al. 1995) and glucagon (Kachra et al. 1991; Uchijima et al. 1995), and to be decreased by GH (Kachra et al. 1991).

\section{Effects of glucose on hepatocyte expression and production}

The major energy source in non-ruminants is glucose, and glucose has been shown to inhibit the gradual decline in GH binding to rat hepatocytes seen when they are cultured in serum-free conditions (Niimi et al. 1991). A similar effect was observed in pig hepatocytes (Brameld et al. 1995b), with high glucose levels reducing the decline in GHR expression with time in culture. Recent work has involved investigating the effects of glucose on GHR expression by pig hepatocytes, and we have demonstrated dose-dependent increases in GHR expression with increased glucose concentration both in the presence and absence of $\mathrm{T}_{3}$ and Dex (Brameld, unpublished results), but only following an initial overnight preincubation without glucose, in order to deplete the hepatocytes of their stored glucose. A lack of glucose was found to be dominant over the added hormones, in that the stimulatory effect of $\mathrm{T}_{3}$ and Dex was only seen in the presence of high concentrations of glucose, or in cells that had not been depleted of glucose. Whether glucose has any effect on IGF-I expression by the pig hepatocytes remains to be seen, but increased glucose has been found either to have no effect (Arany et al. 1993), or to increase (Luo \& MacRae, 1990) IGF-I production by rat hepatocytes.

The only published study on the effects of glucose on IGFBP expression and/or secretion by rat hepatocytes (Arany et al. 1993) shows a decrease in IGFBP-1 mRNA with increased glucose, but no effect on secretion. There was, however, an interaction between glucose and insulin on IGFBP-1 secretion, such that as the glucose concentration increased so insulin became less effective in reducing IGFBP-1 secretion. Thus, at lower (2.7 and $6.5 \mathrm{mM}$ ) glucose concentrations, insulin reduced IGFBP-1 levels in a dose-dependent manner; but, at higher (11.1 mM) glucose concentrations, insulin had no effect on IGFBP-1 levels.

Direct stimulatory effects of glucose, or one of its metabolites, on hepatocyte gene expression have previously been described for a number of genes, including fatty acid synthase ( $E C$ 2.3.1.85; FAS; Prip-Buus et al. 1995), liver pyruvate kinase (EC 2.7.1.40; LPK; Kang et al. 1996), $S_{14}$ (Jacoby et al. 1989), and glucose transporter type 2 (GLUT 2; Rencurel et al. 1996), with glucose also being shown to directly stimulate expression of insulin mRNA by $\beta$-cells in the pancreas (for review, see Docherty \& Clark, 1994). Many of these genes also seem to be dependent on the presence of insulin (FAS, Prip-Buus et al. 1995; LPK, Kang et al. 1996), and to some extent $T_{3}$ and Dex (Prip-Buus et al. 1995), all of which have some effect on pig GHR expression (see p. 613). DNA-binding studies and transfection of suspected gene promoter constructs have revealed glucose response elements (GIRE; for review, see Vaulont \& Kahn, 1994), which have a consensus 
sequence of CACGGG or CACGTG. Whether the pig GHR gene has a similar GIRE in one of its promoters remains to be seen, since the actual number and sequence(s) of GHR promoters in any species remains to be established.

\section{Effects of amino acids on hepatocyte expression and production}

No studies of the effects of altering culture medium amino acid concentrations on pig hepatocyte expression or production of GH-IGF components have been reported to date. However, effects of altering the concentrations of total amino acids in rat hepatocyte culture medium have been studied. Conflicting results have been published on the effects of increasing amino acids on the expression and production of IGF-I and IGFBP-1. Two studies have shown increases in IGF-I mRNA (Phillips et al. 1991; Thissen et al. 1994) and decreases in IGFBP-1 mRNA and production with increased amino acids (Thissen et al. 1994), but another study showed the opposite, with decreases in IGF-I secretion and increases in IGFBP-1 mRNA and production with increased amino acids (Arany et al. 1993). The most recent study (Thissen et al. 1994) also demonstrated interactions between the amino acid concentrations and GH on both IGF-I and IGFBP-1 expression, such that the stimulatory effects of GH on IGF-I expression were enhanced in the presence of the highest amino acid concentrations, whereas the inhibitory effects of GH on IGFBP-1 expression were diminished in the presence of the highest amino acid concentrations. Studies carried out using rat hepatoma cells (a liver-derived cell line) have demonstrated increases in IGFBP-1 mRNA following removal of a single essential amino acid (phenylalanine, methionine, leucine, or tryptophan) from the serum-free culture medium for $24 \mathrm{~h}$ (Straus $e t$ al. 1993).

The current understanding of amino acid-dependent control of gene expression in mammalian cells is very limited, although the evidence suggests that deprivation of one or a number of amino acids leads to an increase in the expression and production of a putative regulatory protein, which in turn alters target gene expression (for review, see Kilberg et al. 1994). However, the identification of this (or these) regulatory proteins is at a very early stage.

\section{CONCLUSIONS}

The molecular mechanisms by which nutrients and hormones interact to control expression of the genes for the various components of the porcine GH-IGF system and, therefore, growth are likely to be very complex. Both the energy component and the protein (amino acid) component of the diet appear to directly control gene expression, in combination with various endocrine hormones also regulated by the diet. No single component of the GH-IGF system is likely to be dominant over the rest and, therefore, it is the overall effect on IGF bioactivity that is important. The energy component (glucose) would appear to be the major regulator of GHR expression, with various hormones also interacting. The protein component (amino acids) has been postulated to directly affect IGF-I expression, but this would appear to be dependent on the GH status of the animal. However, GH is the only factor that has been shown to directly increase the rate of transcription of IGF-I. The functions of the IGFBP are still not clear, but they are also affected, be that directly or indirectly, by diet. The primary regulator of the IGF-1R appears to be IGF-I itself; however, further study of nutrient effects is obviously necessary. Thus, the mechanisms relating to nutrient control of gene expression 
are still unclear, but there is increasing evidence for direct interactions of nutrients in the control of expression of various growth regulatory genes.

The author is grateful to Professor P. J. Buttery and Dr J. M. Dawson for their helpful comments, and the BBSRC for their financial support.

\section{REFERENCES}

Ambler, G. R., Breier, B. H., Surus, A., Blair, H. T., McCutcheon, S. N., Silbergeld, A. \& Gluckman, P. D. (1992). The interrelationship between and the regulation of hepatic growth hormone receptors and circulating GH binding protein in the pig. Acta Endocrinologica 126, 155-161.

Arany, E., Strain, A. J., Hube, M. J., Phillips, I. D. \& Hill, D. J. (1993). Interactive effects of nutrients and hormones on the expression of insulin-like growth factor binding protein-1 (IGFBP-1) mRNA and peptide, and IGF-I release from isolated adult rat hepatocytes. Journal of Cellular Physiology 155, 426435.

Barreca, A., Voci, A., Minuto, F., de Marchis, M., Cecchelli, E., Fugassa, E., Giordano, G. \& Gallo, G. (1992). Effect of epidermal growth factor on insulin-like growth factor-I (IGF-I) and IGF-binding protein synthesis by adult rat hepatocytes. Molecular and Cellular Endocrinology 84, 119-126.

Baumbach, W. R., Horne, D. L. \& Logan, J. S. (1989). The growth hormone-binding protein in the rat serum is an alternatively spliced form of the rat growth hormone receptor. Genes \& Development 3, 1199-1205.

Boni-Schnetzler, M., Schmid, C., Meier, P. J. \& Froesch, E. R. (1991). Insulin regulates insulin-like growth factor I mRNA in rat hepatocytes. American Journal of Physiology 260, E846-E851.

Brameld, J. M., Atkinson, J. L., Budd, T. J., Saunders, J. C., Pell, J. M., Salter, A. M., Gilmour, R. S. \& Buttery, P. J. (1996a). Expression of insulin-like growth factor-I (IGF-I) and growth hormone receptor (GHR) mRNA in liver, skeletal muscle and adipose tissue of different breeds of pig. Animal Science 62, 555-559.

Brameld, J. M., Atkinson, J. L., Saunders, J. C., Pell, J. M., Buttery, P. J. \& Gilmour, R. S. (1996b). Effects of growth hormone administration and dietary protein intake on insulin-like growth factor-I (IGF-I) and growth hormone receptor (GHR) mRNA expression in porcine liver, skeletal muscle and adipose tissue. Joumal of Animal Science 74, 1832-1841.

Brameld, J. M., Weller, P. A., Pell, J. M., Buttery, P. J. \& Gilmour, R. S. (1995a). Ontogenic study of irisulin-like growth factor-I and growth hormone receptor mRNA expression in porcine liver and skeletal miuscle. Animal Science 61, 333-339.

Brameld, J. M., Weller, P. A., Saunders, J. C., Buttery, P. J. \& Gilmour, R. S. (1995b). Hormonal control of insulin-like growth factor-I (IGF-I) and growth hormone receptor (GHR) mRNA expression by porcine hepatocytes in culture. Journal of Endocrinology 146, 239-245.

Breier, B. H. \& Sauerwein, H. (1995). Regulation of growth in ruminants by the somatotropic axis. In Ruminant Physiology: Digestion, Metabolism, Growth and Reproduction. Proceedings of the Eighth International Symposium on Ruminant Physiology, pp. 451-474 [W. V. Engelhardt, S. Leonhard-Marek, G. Breves and D. Giesecke, editors]. Stuttgart, Germany: Ferdinand Enke Verlag.

Buonomo, F. C. \& Baile, C. A. (1991). Influence of nutritional deprivation on insulin-like growth factor I, somatotropin, and metabolic hormones in swine. Joumal of Animal Science 69, 755-760.

Campbell, R. G., Johnson, R. J., King, R. H., Taverner, M. R. \& Meisinger, D. J. (1990). Interaction of dietary protein content and exogenous porcine growth hormone administration on protein and lipid accretion rates in growing pigs. Joumal of Animal Science 68, 3217-3225.

Caperna, T. J., Steele, N. C., Komarek, D. R., McMurtry, J. P., Rosebrough, R. W., Solomon, M. B. \& Mitchell, A. D. (1990). Influence of dietary protein and recombinant porcine somatotropin administration in young pigs: Growth, body composition and hormone status. Journal of Animal Science 68, 4243-4252.

Chung, C. S. \& Etherton, T. D. (1986). Characterization of porcine growth hormone (pGH) binding to porcine liver microsomes: Chronic administration of pGH induces pGH binding. Endocrinology 119, 780-786.

Cioff, J. A., Wang, X. \& Kopchick, J. J. (1990). Porcine growth hormone receptor cDNA sequence. Nucleic Acid Research 18, 6451.

Coleman, M. E. \& Etherton, T. D. (1991). Effects of exogenous growth hormone on serum insulin-like growth factor-binding proteins in growing pigs. Journal of Endocrinology 128, 175-180.

Coleman, M. E., Pan, Y.-C. E. \& Etherton, T. D. (1991). Identification and $\mathrm{NH}_{2}$-terminal amino acid sequence of three insulin-like growth factor-binding proteins in porcine serum. Biochemical and Biophysical Research Communications 181, 1131-1136.

Coleman, M. E., Russell, L. \& Etherton, T. E. (1994). Porcine somatotropin (pST) increases IGF-I mRNA abundance in liver and subcutaneous adipose tissue but not in skeletal muscle of growing pigs. Journal of Animal Science 72, 918-924. 
Dardevet, D., Manin, M., Balage, M., Sornet, C. \& Grizard, J. (1991). Influence of low- and high-protein diets on insulin and insulin-like growth factor-1 binding to skeletal muscle and liver in the growing rat. British Journal of Nutrition $65,47-60$.

Dauncey, M. J., Burton, K. A., White, P., Harrison, A. P., Gilmour, R. S., Duchamp, C. \& Cattaneo, D. (1994). Nutritional regulation of growth hormone receptor gene expression. FASEB Journal 8, 81-88.

Dauncey, M. J. \& Buttle, H. L. (1990). Differences in growth hormone and prolactin secretion associated with environmental temperature and energy intake. Hormone and Metabolic Research 22, 524-527.

Dauncey, M. J., Rudd, B. T., White, D. A. \& Shakespear, R. A. (1993). Regulation of insulin-like growth factor binding proteins in young growing animals by alteration of energy status. Growth Regulation 3, $198-207$.

Dauncey, M. J., Shakespear, R. A., Rudd, B. T. \& Ingram, D. L. (1990). Variations in somatomedin-C/insulinlike growth factor-I associated with environmental temperature and nutrition. Hormone and Metabolic Research 22, 261-264.

Davis, S. L., Graf, M., Morrisson, C. A., Hall, T. R. \& Swift, P. J. (1992). Identification and partial purification of serum growth hormone binding protein in domestic animal species. Journal of Animal Science 70, 773780.

Denver, R. J. \& Nicoll, C. S. (1994). Pancreatic hormones differentially regulate insulin-like growth factor (IGF)-I and IGF-binding protein production by primary rat hepatocytes. Journal of Endocrinology 142, 299310.

Dougherty, K. \& Clark, A. R. (1994). Nutrient regulation of insulin gene expression. FASEB Journal 8, $20-27$.

Evock, C. M., Walton, P. E. \& Etherton, T. D. (1990). Effect of GH status on IGF-I and IGF-II concentrations and serum IGF binding profiles in pigs. Journal of Animal Science 68, 1953-1964.

Gilmour, R. S. (1994). The implications of insulin-like growth factor mRNA heterogeneity. Journal of Endocrinology 140, 1-3.

Glassford, J., Flick-Smith, H. \& Pell, J. M. (1995). Regulation of insulin-like growth factor type-1 receptor (IGFIR) and insulin receptor (IR) gene expression by nutritional status. Journal of Endocrinology 147, Suppl., O40.

Grant, A. L., Helferich, W. G., Kramer, S. A., Merkel, R. A. \& Bergen, W. G. (1991). Administration of growth hormone to pigs alters the relative amount of insulin-like growth factor-1 mRNA in liver and skeletal muscle. Journal of Endocrinology 130, 331-338.

Guan, X. F., Brameld, J. M. \& Buttery, P. J. (1997). Effects of dietary protein levels and porcine growth hormone administration on plasma concentrations of insulin-like growth factor binding proteins in growing pigs. Proceedings of the Nutrition Society 56, 168A.

Harper, J. M. M., Soar, J. B. \& Buttery, P. J. (1987). Changes in protein metabolism of ovine primary muscle cultures on treatment with growth hormone, insulin, insulin-like growth factor-I or epidermal growth factor. Journal of Endocrinology 112, 87-96.

Houston, B. \& O'Neill, I. E. (1991). Insulin and growth hormone act synergistically to stimulate insulin-like growth factor-I production by cultured chicken bepatocytes. Joumal of Endocrinology 128, 389-393.

Hsu, C.-J., Kimball, S. R., Antonetti, D. A. \& Jefferson, L. S. (1992). Effects of insulin on total RNA, poly(A) ${ }^{+}$ RNA, and mRNA in primary cultures of rat hepatocytes. American Journal of Physiology 263, E1106-E1112.

Jacoby, D. B., Zilz, N. D. \& Towle, H. C. (1989). Sequences within the 5 -flanking region of the $S_{14}$ gene confer responsiveness to glucose in primary hepatocytes. Journal of Biological Chemistry 264, 17623-17626.

Jones, J. I. \& Clemmons, D. R. (1995). Insulin-like growth factors and their binding proteins: Biological actions. Endocrine Reviews 16, 3-34.

Kachra, Z., Barash, I., Yannopoulos, C., Khan, M. N., Guyda, H. J. \& Posner, B. I. (1991). The differential regulation by glucagon and growth hormone of insulin-like growth factor (IGF)-I and IGF binding proteins in cultured rat hepatocytes. Endocrinology 128, 1723-1730.

Kang, R., Yamada, K., Tanaka, T., Lu, T. \& Noguchi, T. (1996). Relationship between concentrations of glycolytic intermediates and expression of the L-type pyruvate kinase gene in cultured hepatocytes. Journal of Biochemistry 119, 162-166.

Kelley, R. L., Jungst, S. B., Spencer, T. E., Owsley, W. F., Rahe, C. H. \& Mulvaney, D. R. (1995). Maternal treatment with somatotropin alters embryonic development and early postnatal growth of pigs. Domestic Animal Endocrinology 12, 83-94.

Kelly, P. A., Djiane, J., Postel-Vinay, M. C. \& Edery, M. (1991). The prolactin/growth hormone receptor family. Endocrinology Reviews 12, 235-251.

Kelly, P. A., Goujon, L., Dinerstein, H., Esposito, N., Edery, M., Finidori, J. \& Posten-Vinay, M. C. (1994). The GH receptor and signal transduction. Hormone Research 42, 133-139.

Kilberg, M. S., Hutson, R. G. \& Laine, R. O. (1994). Amino acid-regulated gene expression in eukaryotic cells. FASEB Journal 8, 13-19.

Li, J., Saunders, J. C., Gilmour, R. S., Silver, M. \& Fowden, A. L. (1993). Insulin-like growth factor-II messenger ribonucleic acid expression in fetal tissues of the sheep during late gestation: Effects of cortisol. Endocrinology 132, 2083-2089.

Louveau, I. \& Etherton, T. D. (1992). Partial purification of somatotropin receptors from pig liver: they arise from a single somatotropin receptor messenger RNA transcript. Journal of Animal Science 70, 3421-3428. 
Luo, Q. J. \& MacRae, J. C. (1990). Production of insulin-like growth factor-1 by rat hepatocytes is sensitive to nutrients but not growth hormone. Biochemical Society Transactions 18, 1197-1198.

McCusker, R. H., Campion, D. R., Jones, W. K. \& Clemmons, D. R. (1985). The insulin-like growth factorbinding proteins of porcine serum: endocrine and nutritional regulation. Endocrinology 125, 501-509.

Miura, Y., Higashi, Y., Kato, H., Takahashi, S.-I. \& Noguchi, T. (1992). Effects of dexamethasone on the production of insulin-like growth factor-I and insulin-like growth factor binding proteins in primary cultures of rat hepatocytes. Bioscience Biotechnology and Biochemistry 56, 1396-1400.

Niimi, S., Hayakawa, T., Tanaka, A. \& Ichihara, A. (1991). Glucose regulation of growth hormone receptors in primary cultured rat hepatocytes. Endocrinology 129, 2734-2739.

Oldham, J. M., Martyn, J. A. K., Kirk, S. P., Napier, J. R. \& Bass, J. J. (1996). Regulation of type 1 insulin-like growth factor (IGF) receptors and IGF-I mRNA by age and nutrition in ovine skeletal muscles. Journal of Endocrinology 148, 337-346.

Owens, P. C., Johnson, R. J., Campbell, R. G. \& Ballard, F. J. (1990). Growth hormone increases insulin-like growth factor-I (IGF-I) and decreases IGF-II in plasma of growing pigs. Journal of Endocrinology 124, 269275.

Phillips, L. S., Goldstein, S. \& Pao, C.-I. (1991). Nutrition and somatomedin XXVI. Molecular regulation of IGF-I by insulin in cultured rat hepatocytes. Diabetes 40, 1525-1530.

Prip-Buus, C., Perdereau, D., Foufelle, F., Maury, J., Ferre, P. \& Girard, J. (1995). Induction of fatty-acidsynthase gene expression by glucose in primary culture of rat hepatocytes: Dependency upon glucokinase activity. European Journal of Biochemistry 230, 309-315.

Ramsay, T. G., Chung, I. B., Czerwinski, S. M., McMurtry, J. P., Rosebrough, R. W. \& Steele, N. C. (1995). Tissue IGF-I protein and mRNA responses to a single injection of somatotropin. American Journal of Physiology 269, E627-E635.

Rechler, M. M. \& Brown, A. L. (1992). Insulin-like growth factor binding proteins: Gene structure and expression. Growth Regulation 2, 55-68.

Rencurel, F., Waeber, G., Antoine, B., Rocchiccioli, F., Maulard, P., Girard, J. \& Leturque, A. (1996). Requirement of glucose metabolism for regulation of glucose transporter type 2 (GLUT2) gene expression in liver. Biochemical Journal 314, 903-909.

Roe, J. A., Haji Baba, A. S., Harper, J. M. M. \& Buttery, P. J. (1995). Effects of growth factors and gut regulatory peptides on nutrient uptake in ovine muscle cell cultures. Comparative Biochemistry and Physiology 110A, 107-114.

Roe, J. A., Harper, J. M. M. \& Buttery, P. J. (1989). Protein metabolism in ovine primary muscle cultures derived from satellite cells - effects of selected peptide hormones and growth factors. Journal of Endocrinology 122, 565-571.

Seve, B., Ballevre, O., Ganier, P., Noblet, J., Prugnaud, J. \& Obled, C. (1993). Recombinant porcine somatotropin and dietary protein enhance protein synthesis in growing pigs. Journal of Nutrition 123, 529-540.

Sorensen, M. T., Chaudhuri, S., Louveau, I., Coleman, M. E. \& Etherton, T. D. (1992). Growth hormone binding proteins in pig adipose tissue: number, size and effects of pGH treatment on pGH and bGH binding. Domestic Animal Endocrinology 9, 13-24.

Straus, D. S., Burke, E. J. \& Marten, N. W. (1993). Induction of insulin-like growth factor binding protein-1 gene expression in liver of protein-restricted rats and in rat hepatoma cells limited for a single amino acid. Endocrinology 132, 1090-1100.

Sussenbach, J. S., Steenbergh, P. H. \& Holthuizen, P. (1992). Structure and expression of the human insulin-like growth factor genes. Growth Regulation 2, 1-9.

Thissen, J.-P., Pucilowska, J. B. \& Underwood, L. E. (1994). Differential regulation of insulin-like growth factor-I (IGF-I) and IGF binding protein-1 messenger ribonucleic acids by amino acid availability and growth hormone in rat hepatocyte primary culture. Endocrinology 134, 1570-1576.

Trivedi, B. \& Daughaday, W. H. (1988). Release of growth hormone binding protein from IM-9 lymphocytes by endopeptidase digestion is dependent on sulfydryl group inactivation. Endocrinology 123, 2201-2206.

Uchijima, Y., Takenaka, A., Takahashi, S.-I. \& Noguchi, T. (1995). Production of insulin-like growth factors and their binding proteins in primary cultures of rat liver parenchymal and nonparenchymal cells. Bioscience Biotechnology and Biochemistry 58, 1503-1515.

van Neste, L., Husman, B., Moller, C., Andersson, G. \& Norstedt, G. (1988). Cellular distribution of somatogenic receptors and insulin-like growth factor-I mRNA in the rat liver. Journal of Endocrinology 119, $69-74$.

Vaulont, S. \& Kahn, A. (1994). Transcriptional control of metabolic regulation genes by carbohydrates. FASEB Journal 8, 28-35.

Weller, P. A., Dauncey, M. J., Bates, P. C., Brameld, J. M., Buttery, P. J. \& Gilmour, R. S. (1994). Regulation of porcine insulin-like growth factor-I and growth hormone receptor mRNA expression by energy status. American Joumal of Physiology 266, E776-E785.

Weller, P. A., Dickson, M. C., Huskisson, N. S., Dauncey, M. J., Buttery, P. J. \& Gilmour, R. S. (1993). The porcine insulin-like growth factor-I gene: characterization and expression of alternate transcription sites. Journal of Molecular Endocrinology 11, 201-211. 
Werner, H., Hernandez-Sanchez, C., Karnieli, E. \& LeRoith, D. (1995). The regulation of IGF-I receptor gene expression. International Journal of Biochemistry and Cell Biology 27, 987-994.

Wolverton, C. K., Azain, M. J., Duffy, J. Y., White, M. E. \& Ramsay, T. G. (1992). Influence of somatotropin on lipid metabolism and IGF gene expression in porcine adipose tissue. American Journal of Physiology 263, E637-E645.

Zapf, J. (1995). Physiological role of the insulin-like growth factor binding proteins. European Journal of Endocrinology 132, 645-654. 